\title{
A Metalloproteinase Induces an Inflammatory Response in Preadipocytes with the Activation of COX Signalling Pathways and Participation of Endogenous Phospholipases $\mathbf{A}_{2}$
}

\author{
Priscila Motta Janovits $1,2, *$, Elbio Leiguez ${ }^{1,2}$, Viviane Portas ${ }^{2,3}$ and Catarina Teixeira $1,2, *$ (D) \\ 1 Laboratório de Farmacologia, Instituto Butantan, São Paulo 05503-900, Brazil; elbio.leiguez@butantan.gov.br \\ 2 Centre of Excellence in New Target Discovery (CENTD), Instituto Butantan, São Paulo 05503-900, Brazil; \\ viviane.portas@butantan.gov.br \\ 3 Laboratório de Desenvolvimento e Inovação, Instituto Butantan, São Paulo 05503-900, Brazil \\ * Correspondence: priscilajanovits@gmail.com (P.M.J.); catarina.teixeira@butantan.gov.br (C.T.)
}

Citation: Janovits, P.M.; Leiguez, E.;

Portas, V.; Teixeira, C. A

Metalloproteinase Induces an

Inflammatory Response in

Preadipocytes with the Activation of

COX Signalling Pathways and

Participation of Endogenous

Phospholipases $\mathrm{A}_{2}$. Biomolecules 2021,

11, 921. https://doi.org/10.3390/

biom 11070921

Academic Editors: George Kokotos and Sasanka Ramanadham

Received: 2 April 2021

Accepted: 11 June 2021

Published: 22 June 2021

Publisher's Note: MDPI stays neutral with regard to jurisdictional claims in published maps and institutional affiliations.

Copyright: (c) 2021 by the authors. Licensee MDPI, Basel, Switzerland. This article is an open access article distributed under the terms and conditions of the Creative Commons Attribution (CC BY) license (https:// creativecommons.org/licenses/by/ $4.0 /)$.

\begin{abstract}
Matrix metalloproteinases (MMPs) are proteolytic enzymes that have been associated with the pathogenesis of inflammatory diseases and obesity. Adipose tissue in turn is an active endocrine organ capable of secreting a range of proinflammatory mediators with autocrine and paracrine properties, which contribute to the inflammation of adipose tissue and adjacent tissues. However, the potential inflammatory effects of MMPs in adipose tissue cells are still unknown. This study investigates the effects of BmooMP $\alpha$-I, a single-domain snake venom metalloproteinase (SVMP), in activating an inflammatory response by 3T3-L1 preadipocytes in culture, focusing on prostaglandins (PGs), cytokines, and adipocytokines biosynthesis and mechanisms involved in prostaglandin $\mathrm{E}_{2}$ $\left(\mathrm{PGE}_{2}\right)$ release. The results show that $\mathrm{BmooMP} \alpha-\mathrm{I}$ induced the release of $\mathrm{PGE}_{2}$, prostaglandin $\mathrm{I}_{2}$ $\left(\mathrm{PGI}_{2}\right)$, monocyte chemoattractant protein-1 (MCP-1), and adiponectin by preadipocytes. BmooMP $\alpha-$ I-induced $\mathrm{PGE}_{2}$ biosynthesis was dependent on group-IIA-secreted phospholipase $\mathrm{A}_{2}$ (sPLA $\mathrm{s}_{2}$-IIA), cytosolic phospholipase $\mathrm{A}_{2}-\alpha\left(\mathrm{CPLA}_{2}-\alpha\right)$, and cyclooxygenase (COX)- 1 and -2 pathways. Moreover, BmooMP $\alpha$-I upregulated COX-2 protein expression but not microsomal prostaglandin E synthase-1 (mPGES-1) expression. In addition, we demonstrate that the enzymatic activity of BmooMP $\alpha$ I is essential for the activation of prostanoid synthesis pathways in preadipocytes. These data highlight preadipocytes as important targets for metalloproteinases and provide new insights into the contribution of these enzymes to the inflammation of adipose tissue and tissues adjacent to it.
\end{abstract}

Keywords: metalloproteinase; preadipocytes; prostaglandins; adipokines; cytokines

\section{Introduction}

MMPs are a family of zinc-dependent endoproteases responsible for the degradation of various proteins of the extracellular matrix (ECM). In physiological conditions, when the expression and activity of MMPs are under strict control, these enzymes play important roles in tissue remodelling, host defense, angiogenesis, and immune response, as well as cell proliferation, migration, and differentiation [1-4]. However, when there is an imbalance between the levels of activated MMPs and their tissue inhibitors, these enzymes become important in the pathogenesis of several inflammatory diseases, such as arthritis, atherosclerosis, and obesity [1,3,5-9]. Although the precise mechanisms of action of MMPs have not been completely described, these enzymes have been shown to trigger inflammatory reactions at various levels, regulating the recruitment of inflammatory cells to the site of inflammation by the processing of ECM components, growth factors, cytokines, and chemokines [1,10-12]. Accordingly, increased circulating plasma levels of MMPs and increased expression of these enzymes, mainly of MMP-3, MMP-9, and MMP-13, have been reported in the inflamed tissues of patients suffering from inflammatory diseases, such as rheumatoid arthritis, osteoarthritis, bowel disease, and neuroinflammation $[1,3,8,10]$. 
Presently, MMPs have been associated with the development of obesity by promoting adipocyte differentiation, as well as adipose tissue remodelling [5,13-16]. In this context, levels of MMP-2, MMP-8, and MMP-9 were found to be increased in the adipose tissue of obese patients $[5,6,13]$. However, despite the roles of MMPs in obesity development, the actions of these enzymes on adipose tissue cells are still unknown.

Adipose tissue is known to secrete a range of proinflammatory mediators with autocrine and paracrine properties, such as the adipose-tissue-derived adipokines leptin, resistin, and adiponectin; cytokines; chemokines; and PGs, which contribute to the development and progression of inflammatory diseases [17-23]. Among the mediators produced by the adipose tissue, $\mathrm{PGE}_{2}$, which is enzymatically converted from arachidonic acid (AA) by the COXs and terminal PGE synthases (PGES), is the predominant PG produced by the adipose tissue and plays a pivotal role in the pathogenesis of several inflammatory diseases $[20,24,25]$. In inflammatory conditions, $\mathrm{PGE}_{2}$ is known to mediate vasodilation, vascular permeability, and pain [26,27]. Regarding obesity, $\mathrm{PGE}_{2}$ has been implicated in the regulation of adipose tissue functions and the development of obesity. In this regard, $\mathrm{PGE}_{2}$ and COX-2 levels have been found to be increased in the adipose tissue of obese patients [20,28-31]. Despite modulatory effects in this tissue by the suppression of leukocyte inflammatory activity, several pieces of evidence have shown that $\mathrm{PGE}_{2}$ exerts antilipolytic actions that lead to increased adipose tissue mass, a factor that has been associated with increased risk of diabetes and cardiovascular disease [20,31-34].

Adipose tissue is largely composed of two fractions, mature adipocytes and the stromal vascular fraction (SVF), which is responsible for the generation of many of the proinflammatory mediators secreted by this tissue [35]. Within the SVF, preadipocytes, the undifferentiated precursors of mature adipocytes, account for up to $50 \%$ of the cells in human adipose tissue, and when compared to mature adipocytes, have a propensity for greater inflammatory response through the activation of nuclear factor- $\mathrm{kB}(\mathrm{NF}-\mathrm{kB})$ and mitogen-activated protein kinase (MAPK) signalling [35-37]. In the adipose tissue, MMPs are known to participate in the differentiation of preadipocytes into mature adipocytes and in the development of this tissue by promoting ECM remodelling [7,38-40]. However, the inflammatory actions of MMPs in adipose tissue cells and mechanisms leading to the production of $\mathrm{PGE}_{2}$ in these cells are still unknown.

SVMPs share structural and functional homology with mammalian MMPs and have been grouped within the M12 family of metalloproteinases, which belong to the metzincin superfamily of these proteinases [41,42]. This superfamily is characterised by the presence of a consensus zinc-binding sequence (HEXXHXXGXXH) followed by a conserved loop, Met-turn, in the catalytic domain [1,2,42,43]. The SVMPs have been classified into three main classes (P-I to P-III) based on their domain structure and size. Notably, P-I class SVMPs present only the catalytic metalloproteinase domain, and as with MMPs, are able to degrade ECM components, activate inflammatory cells, and induce inflammatory events in several experimental models. P-I SVMPs are, therefore, useful tools for studies of the biological effects of MMPs, including inflammatory disease development [44-46].

Based on this, we investigated the ability of BmooMP $\alpha$-I, a P-I class metalloproteinase isolated from Bothrops moojeni snake venom, to activate the inflammatory response by preadipocytes in culture with a focus on (i) the release of $\mathrm{PGE}_{2}$ and $\mathrm{PGI}_{2}$, cytokines, and adipokines; and (ii) the mechanisms involved in the release of $\mathrm{PGE}_{2}$ induced by this metalloproteinase. For this purpose, we evaluated the participation of COX-1, COX-2, mPGES-1, endogenous $\mathrm{PLA}_{2} \mathrm{~s}$, and metalloproteinase catalytic activity in the BmooMP $\alpha$-I-induced release of $\mathrm{PGE}_{2}$. Our results are the first to demonstrate the ability of a metalloproteinase to activate preadipocytes for production of $\mathrm{PGE}_{2}, \mathrm{PGI}_{2}$, monocyte chemoattractant protein 1 (MCP-1), and adiponectin. The BmooMP $\alpha$-I-induced production of $\mathrm{PGE}_{2}$ is dependent on the activation of endogenous $\mathrm{CPLA}_{2}-\alpha$ and sPLA 2 -IIA and the COX-1/COX-2/mPGES- 1 pathway. The catalytic activity of BmooMP $\alpha$-I is critical for the activation of PG biosynthesis pathways. 


\section{Materials and Methods}

\subsection{Chemicals and Reagents}

MTT and L-glutamine were obtained from USB (Cleveland, OH, USA). Dulbecco's modified Eagle's medium (DMEM) and fetal bovine serum (FBS) were purchased from Life Technologies (São Paulo, SP, Brazil). Gentamicin was purchased from Schering-Plough (Whitehouse Station, NJ, USA) and DMSO was purchased from Amresco (Solon, OH, USA). Mouse $\mathrm{mAb}$ anti- $\beta$-actin was purchased from Sigma-Aldrich (St. Louis, MO, USA) and polyclonal antibodies against COX-1, COX-2 and mPGES-1 were purchased from Cayman Chemical Company (Ann Arbor, MI, USA). $\mathrm{PGE}_{2} ; \mathrm{PGI}_{2}$ enzyme immunoassay kit; and the compounds SC-560 NS-398, pyrrolidine-2 (PYR-2), FKGK11, KH064, and Batimastat (BB-94) were also purchased from Cayman Chemical Company (Ann Arbor, MI, USA). Secondary antimouse and antirabbit antibodies conjugated to HRP and nitrocellulose membrane were obtained from GE Healthcare (Buckinghamshire, UK), while the leptin, resistin, and adiponectin immunoassay kit was purchased from Thermo Fisher Scientific (Waltham, MA, USA). The cytometric bead assay (CBA) kit was purchased from BD Bioscience (San Jose, CA, USA).

\subsection{BmooMPa-I}

The metalloproteinase BmooMP $\alpha$-I, isolated from Bothrops moojeni venom, was purified by ion-exchange chromatography on a Hitrap ${ }^{\circledR}$ DEAE Fast Flow column. Gel filtration was performed on a Tosoh G2000SWxL column and affinity chromatography was performed on a Hitrap ${ }^{\circledR}$ Heparin High Performance column [47]. All chromatographic steps were performed using liquid chromatography on AKTA AVANT from GE Healthcare (Buckinghamshire, UK). The homogeneity of the enzyme was determined by sodium dodecyl sulphate-polyacrylamide gel electrophoresis (SDS-PAGE) under reducing conditions and confirmed by mass spectrometry. The results obtained via mass spectrometry demonstrated a single protein peak with a molecular weight of $24.5 \mathrm{kDa}$ compatible with the metalloproteinase BmooM $\alpha$-I. The proteolytic activity of BmooMP $\alpha$-I was confirmed using the fluorescence resonance energy transfer substrate (FRET Abz-FRSSRQ-EDDnp), which contains a universal sequence recognized by different classes of proteases [48]. The absence of endotoxin contamination in the BmooMPa-I batches used was demonstrated by the quantitative limulus amebocyte lysate (LAL) test [49], which revealed undetectable levels of endotoxin $(<0.125 \mathrm{EU} / \mathrm{mL})$. The enzyme was lyophilised, stored at $-20{ }^{\circ} \mathrm{C}$, and dissolved in DMEM medium just before use.

\subsection{Cytotoxicity Assay}

The cytotoxicity of BmooMP $\alpha$-I toward the 3T3-L1 preadipocyte was evaluated using the MTT assay as previously described [50]. In brief, $4 \times 10^{3}$ preadipocytes per well were plated in 96-well plates in DMEM, supplemented with $40 \mu \mathrm{g} / \mathrm{mL}$ gentamicin sulphate and $2 \mathrm{mM}$ L-glutamine, then incubated with BmooMP $\alpha$-I $(0.24 \mu \mathrm{M}), \mathrm{COX}$, or PLA 2 inhibitors or Batimastat diluted in medium or with the same volume of medium alone (control) for 1 , $3,6,12,24$, and $48 \mathrm{~h}$ in a humidified atmosphere $\left(5 \% \mathrm{CO}_{2}\right)$ at $37^{\circ} \mathrm{C}$. MTT $(5 \mathrm{mg} / \mathrm{mL})$ was dissolved in PBS and filtered for the removal of insoluble residues and sterilisation. MTT stock solution ( $10 \%$ in culture medium) was added to all wells in each assay and plates were incubated for $3 \mathrm{~h}$ at $37^{\circ} \mathrm{C}$. Dimethyl sulfoxide (DMSO) $(100 \mu \mathrm{L})$ was added to wells and mixed thoroughly for $30 \mathrm{~min}$ at room temperature. Absorbances were then recorded at $540 \mathrm{~nm}$ in a microtiter plate reader. The results were expressed as percentages of viable cells, considering control cells incubated with medium alone as $100 \%$ viable.

\subsection{T3-L1 Cell Culture and Stimulation}

The 3T3-L1 preadipocytes obtained from the American Type Culture Collection were cultured as described in a previous study [35]. Briefly, $5 \times 10^{3}$ preadipocytes per well were seeded in 12-well culture plates and maintained in culture medium for $48 \mathrm{~h}$ before stimulation, according to the experimental protocol. Preadipocytes were serum-starved in 
DMEM containing 1\% $(v / v)$ gentamicin sulphate supplemented with $1 \%(v / v)$ L-glutamine for $18 \mathrm{~h}$ prior to all treatments. Cell homogenates were collected and used for the Western blotting analysis of COX-1, COX-2, and mPGES-1 protein expression, and supernatants of each treatment were used to measure lipid mediators $\mathrm{PGE}_{2}$ and $\mathrm{PGI}_{2}$ and the adipokines leptin, resistin, and adiponectin by enzyme immunoassay (EIA), as well as the cytokines MCP-1, TNF- $\alpha$, IL-1 $\beta$, KC, IL- 6 , and IL-10 by cytometric bead array (CBA). Cells were stimulated with BmooMP $\alpha-\mathrm{I}(0.24 \mu \mathrm{M})$, diluted in DMEM (2.5\% FBS) or DMEM alone (control) for selected periods, and maintained in a humidified atmosphere $\left(5 \% \mathrm{CO}_{2}\right)$ at $37^{\circ} \mathrm{C}$. To investigate the mechanism involved in the $\mathrm{PGE}_{2}$ biosynthesis and the participation of the metalloproteinase enzymatic activity in the effects induced by BmooMP $\alpha-\mathrm{I}$, selective inhibitors were used at previously tested concentrations: $1 \mu \mathrm{M}$ SC-560 (COX-1 inhibitor) [51] and NS-398 (COX-2 inhibitor) [52], $1 \mu \mathrm{M}$ PYR-2 (cPLA $2-\alpha$ inhibitor) [53], $1 \mu \mathrm{M}$ FKGK11 (calcium-independent phospholipase $\mathrm{A}_{2}$ (iPLA $\mathrm{i}_{2}$ ) inhibitor) [54], $10 \mu \mathrm{M}$ KH064 (sPLA 2 -IIA inhibitor) [55], and $32 \mu \mathrm{M}$ Batimastat (metalloproteinase inhibitor) [56]. All stock solutions were prepared in DMSO and stored at $-20^{\circ} \mathrm{C}$. Aliquots were diluted in DMEM immediately before use. The concentration of DMSO was always lower than $1 \%$. The viability of cells treated with inhibitors was evaluated by MTT assay. No significant changes in cell viability were registered with any of the tested agents or the vehicle at the concentrations used.

\subsection{Inhibition of Metalloproteinase Activity}

BmooMP $\alpha$-I was incubated with the peptidomimetic hydroxamate metalloproteinase inhibitor Batimastat $(32 \mu \mathrm{M})$ at $37^{\circ} \mathrm{C}$ for $30 \mathrm{~min}$ prior to incubation with cells [56]. The 3T3-L1 preadipocytes plated in 12-well plates were then incubated for $6 \mathrm{~h}$ at $37^{\circ} \mathrm{C}$ with aliquots of $\mathrm{BmooMP} \alpha-\mathrm{I}(0.24 \mu \mathrm{M})$ inhibited by Batimastat and controls, which included $\mathrm{BmooMP} \alpha$-I without Batimastat, Batimastat alone, or vehicle (DMSO). Cell homogenates were collected for the evaluation of COX-2 protein expression and supernatants were collected for the quantification of $\mathrm{PGE}_{2}$.

\subsection{Western Blotting}

The protein expression of COX-1, COX-2, and mPGES-1 from cell homogenates was detected by Western blotting. Briefly, BmooMP $\alpha$-I-stimulated and non-stimulated cells were lysed with $100 \mathrm{~mL}$ of a sample buffer (0.5 M Tris $\mathrm{HCl}, \mathrm{pH}$ 6.8, 20\% SDS, 1\% glycerol, $1 \mathrm{M} \beta$-mercaptoethanol, $0.1 \%$ bromophenol blue) and boiled for $10 \mathrm{~min}$. Samples were resolved by SDS-PAGE on $10 \%$ bis-acrylamide gels overlaid with a 5\% stacking gel. Proteins were transferred to nitrocellulose membranes using a Mini Trans-Blot system (Bio-Rad Laboratories, Richmond, CA, USA). Membranes were then blocked for $1 \mathrm{~h}$ with 5\% albumin in Tris-buffered saline (20 mM Tris, $100 \mathrm{mM} \mathrm{NaCl}$ and $0.5 \%$ Tween 20, $\mathrm{pH}$ 7.2) and incubated overnight at room temperature with primary antibodies against COX-1, COX-2, and mPGES-1 (1:500 dilution) or for $1 \mathrm{~h}$ with the primary antibody against $\beta$-actin (1:3000 dilution). Membranes were washed and incubated with the appropriate secondary antibody conjugated to horseradish peroxidase. Immunoreactive bands were detected by the entry-level peroxidase substrate for enhanced chemiluminescence, according to the instructions of the manufacturer (GE Healthcare). Band densities were quantified with an ImageQuant LAS 4000 mini densitometer (GE Healthcare) using the image analysis software ImageQuant TL (GE Healthcare).

\subsection{Prostanoid, Cytokine and Adipokine Quantification}

$\mathrm{PGE}_{2}$ and $\mathrm{PGI}_{2}$, as well as the adipokines leptin, resistin, and adiponectin, were measured using EIA kits, while cytokines (MCP-1, TNF- $\alpha$, IL-1 $\beta$, KC, IL-6, IL-10) were quantified using a CBA kit from supernatants of preadipocytes incubated with each treatment. Kits were used following the instructions of the manufacturer. 


\subsection{Statistical Analysis}

Data are expressed as means \pm SEM $(n=3-4)$. Multiple comparisons among groups were performed using ANOVA, and as a post-test, the Bonferroni test. Differences between experimental groups were considered significant for $p$-values $<0.05$. All statistical tests were performed using GraphPad Prism version 5 software (GraphPad, San Diego, CA, USA).

\section{Results}

3.1. Metalloproteinase BmooMP $\alpha-I$ Induces the Release of $P G E_{2}$ and $P G I_{2}$ by Cultured Preadipocytes

$\mathrm{PGE}_{2}$ and $\mathrm{PGI}_{2}$ are recognised as key mediators for the pathogenesis of inflammatory diseases [57-60]. $\mathrm{PGE}_{2}$ has been reported to be released by macrophages upon MMP stimulus [61]; however, whether this class of enzymes stimulates preadipocytes to release $\mathrm{PGE}_{2}$ and $\mathrm{PGI}_{2}$ has yet to be established. To investigate the action of BmooMP $\alpha-\mathrm{I}$ in preadipocytes, we first assessed the ability of this metalloproteinase to induce the release of $\mathrm{PGE}_{2}$ in cultured preadipocytes by testing three concentrations of BmooMP $\alpha-\mathrm{I}(0.06$, 0.12 , and $0.24 \mu \mathrm{M})$, which were added to the culture for $24 \mathrm{~h}$. At these concentrations, BmooMP $\alpha$-I did not affect cell viability after 6 or $24 \mathrm{~h}$ of incubation, as assessed by MTT assay. After establishing that $\mathrm{BmooMP} \alpha-\mathrm{I}$ induced a maximal effect at $0.24 \mu \mathrm{M}$ (Figure $1 \mathrm{~A}$ ), we evaluated the time course of $\mathrm{PGE}_{2}$ and $\mathrm{PGI}_{2}$ release induced by $\mathrm{BmooMP} \alpha-\mathrm{I}$. To that end, $\mathrm{BmooMP} \alpha-\mathrm{I}(0.24 \mu \mathrm{M})$ was added to the culture for $1,3,6,12$, and $24 \mathrm{~h}$, and $\mathrm{PGE}_{2}$ and $\mathrm{PGI}_{2}$ release was evaluated by ELISA. As shown in Figure $1 \mathrm{~B}, \mathrm{BmooMP} \alpha-\mathrm{I}$ induced a significant release of $\mathrm{PGE}_{2}$ from 3 to $24 \mathrm{~h}$ and of $\mathrm{PGI}_{2}$ from 12 to $24 \mathrm{~h}$ (Figure 1C) when compared with control cells incubated with culture medium alone. These results indicate that $\mathrm{BmooMP} \alpha-\mathrm{I}$ has the ability to directly stimulate preadipocytes to produce prostanoids.

\subsection{BmooMP $\alpha-I-I n d u c e d$ Release of PGE 2 Is Dependent on COX-1 and COX-2}

COX-1 and COX-2 are key enzymes responsible for the production of prostanoids from AA [62]. COX-2 expression is induced by inflammatory stimuli and has largely been associated with the increased production of PGs in inflammatory conditions [63,64]. In addition, $\mathrm{PGE}_{2}$ is one of the most abundant lipid mediators produced in the adipose tissue [25]. Therefore, to investigate the mechanisms underlying $\mathrm{PGE}_{2}$ release induced by the metalloproteinase BmooMP $\alpha$-I in preadipocytes, we evaluated the participation of COX-1 and COX-2 in this effect. Preadipocytes were treated for $1 \mathrm{~h}$ with either compound SC-560 or compound NS-398, selective inhibitors of COX-1 and COX-2, respectively, or their vehicle. $\mathrm{PGE}_{2}$ release was evaluated after $12 \mathrm{~h}$ of incubation with BmooMP $\alpha$-I. As shown in Figure 2A, preadipocytes preincubated with vehicle followed by stimulation with BmooMP $\alpha$-I induced significant release of $\mathrm{PGE}_{2}$ when compared with basal preadipocytes (negative control). Pretreatment of cells with SC-560 abolished BmooMP $\alpha$-I-induced PGE 2 release in comparison with preadipocytes treated with vehicle followed by stimulation with BmooMP $\alpha$-I (positive control). Pretreatment of cells with NS-398 significantly reduced the release of $\mathrm{PGE}_{2}$ induced by BmooMP $\alpha$-I (Figure 2A) in comparison with the positive control; pretreatment of preadipocytes with the association of both SC-560 and NS-398 abolished this release when compared with the positive control. These results suggest that both COX-1 and COX-2 play an important role in $B m o o M P \alpha-I-i n d u c e d \mathrm{PGE}_{2}$ production in preadipocytes. Based on the above results, we next investigated whether BmooMP $\alpha$-I can induce the protein expression of COX-1 and COX- 2 by preadipocytes. As demonstrated in Figure 2B,C, the incubation of cells with BmooMP $\alpha$-I did not affect the constitutive expression of COX-1 in comparison with the basal control but it significantly increased the protein expression of COX-2 after $3 \mathrm{~h}$ and up to $24 \mathrm{~h}$ of incubation (Figure 2B,D). Taken together, these findings indicate that the production of $\mathrm{PGE}_{2}$ induced by BmooMP $\alpha$ I depends on the COX-1 and COX-2 signalling pathways and suggest that the ability of $\mathrm{BmooMP} \alpha-\mathrm{I}$ to upregulate COX-2 expression at the translational level is one of the mechanisms of the increased production of $\mathrm{PGE}_{2}$ seen at the later time interval $(24 \mathrm{~h})$. 
A

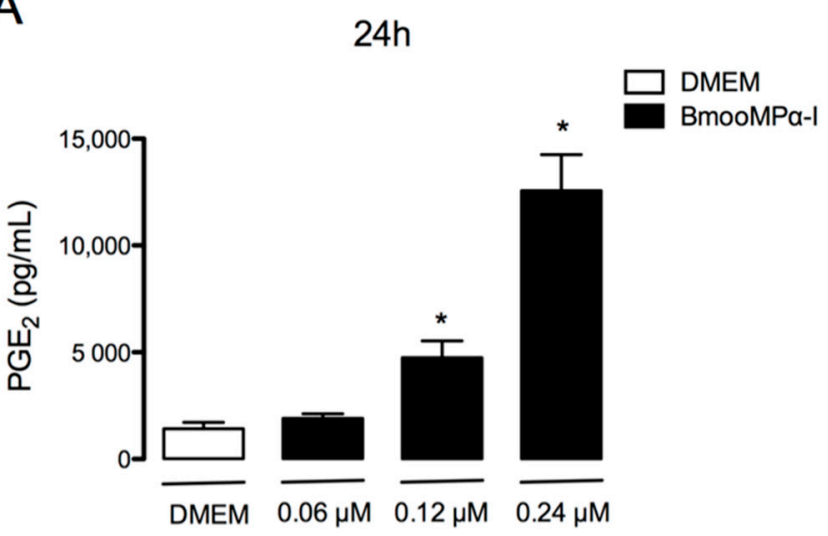

B

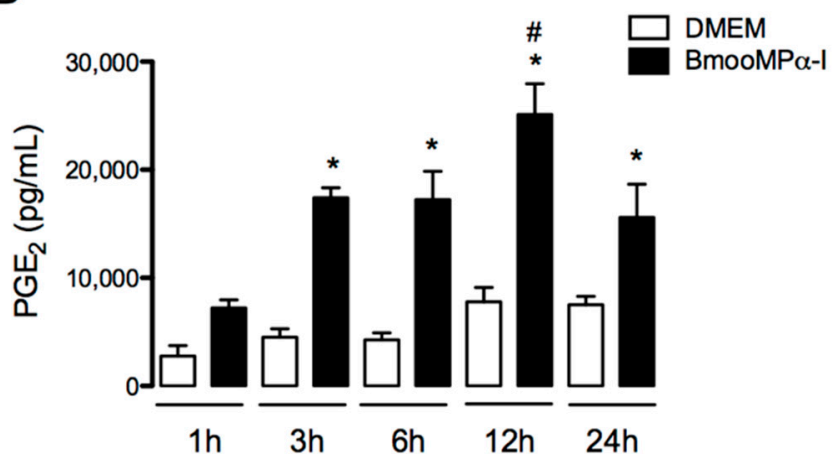

C

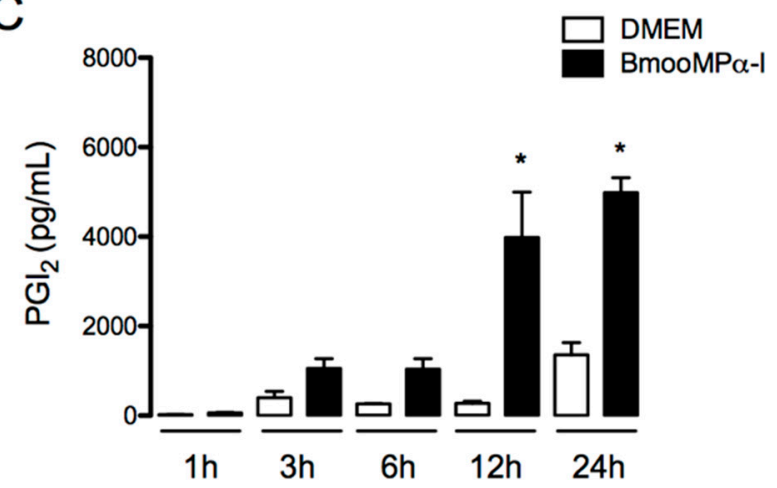

Figure 1. BmooMP $\alpha$-I induces production of $\mathrm{PGE}_{2}$ and $\mathrm{PGI}_{2}$ by preadipocytes: $(\mathrm{A})$ effects of selected concentrations of BmooMP $\alpha$-I in the release of $\mathrm{PGE}_{2}$ at $24 \mathrm{~h}$; (B) time-course of BmooMP $\alpha$-I-induced release of PGE $\mathrm{B}_{2}$ (C) time-course of BmooMP $\alpha$-I-induced release of $\mathrm{PGI}_{2}$. Preadipocytes were incubated with BmooMP $\alpha-\mathrm{I}(0.06,0.12$, or $0.24 \mu \mathrm{M})$ or DMEM (control) for 1, 3, 6, 12, or $24 \mathrm{~h}$. Concentrations of $\mathrm{PGE}_{2}$ and $\mathrm{PGI}_{2}$ in culture supernatants were determined by EIA. Results are expressed as means \pm SEM of 3 experiments. Note: ${ }^{*} p<0.05$ vs. control; ${ }^{*} p<0.05$ vs. BmooMP $\alpha-I$ (two-way ANOVA and Bonferroni post-test).

\subsection{BmooMP $\alpha$-I Induces mPGES-1 Protein Expression}

Since mPGES-1 is an inducible enzyme responsible for the final step of the PGE 2 biosynthetic cascade [62], we further explored the mechanisms involved in $\mathrm{BmooMP} \alpha-$ I-induced PGE $_{2}$ production in preadipocytes by assessing mPGES-1 protein expression after stimulation with the metalloproteinase. Figure 3A,B shows that the stimulation of cells with BmooMP $\alpha$-I did not alter mPGES-1 protein expression when compared with control cells, suggesting that this mechanism is not involved in the BmooMP $\alpha$-I-induced production of $\mathrm{PGE}_{2}$.

3.4. Metalloproteinase Enzymatic Activity Is Important for BmooMP $\alpha$-I-Induced Release of PGE 2 and COX-2 Expression

The catalytic domain is conserved among all classes of the metalloproteinase enzyme superfamily [2]. Therefore, to investigate the importance of the enzymatic activity of metalloproteinases in the effects triggered by BmooMP $\alpha$-I in preadipocytes, in particular in the release of $\mathrm{PGE}_{2}$ and protein expression of COX-2, two fundamental events in inflammation, the catalytic domain of this enzyme was inhibited by incubation with the compound Batimastat. Batimastat is a hydroxamate peptidomimetic that binds specially to zinc ions in MMPs and inhibits enzyme activities [64,65]. As shown in Figure 4, the inhibition of the enzymatic site of BmooMP $\alpha$-I abolished the release of PGE 2 (Figure 4A) and COX-2 expression (Figure 4B,C) after $6 \mathrm{~h}$ of incubation when compared with the positive control 
incubated with the active enzyme. This indicates that the enzymatic activity of BmooMP $\alpha-\mathrm{I}$ is important for the activation of prostanoid synthesis pathways in preadipocytes.

A

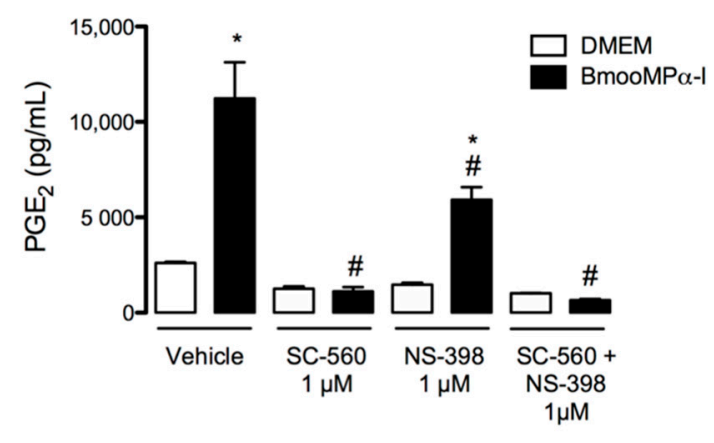

B

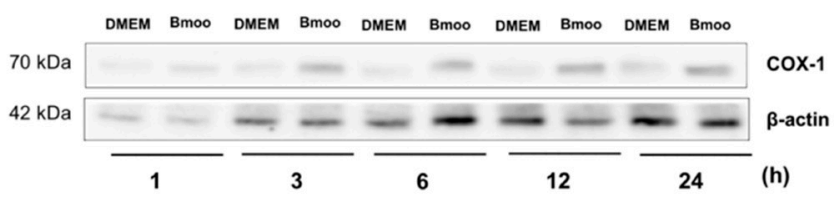

C

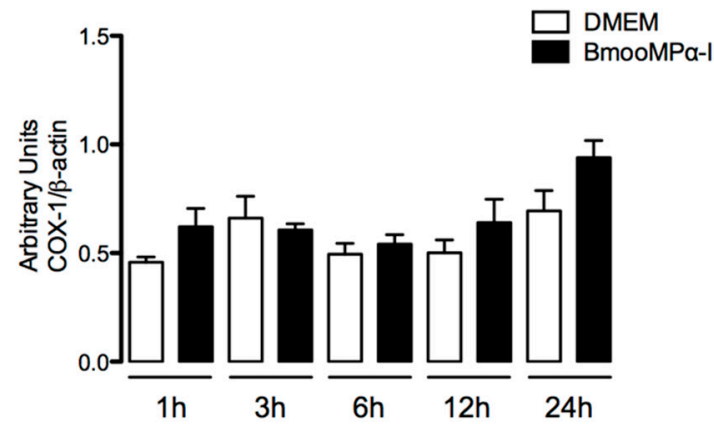

$\mathrm{D}$

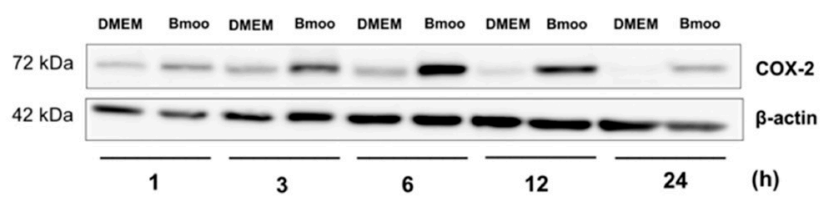

$E$

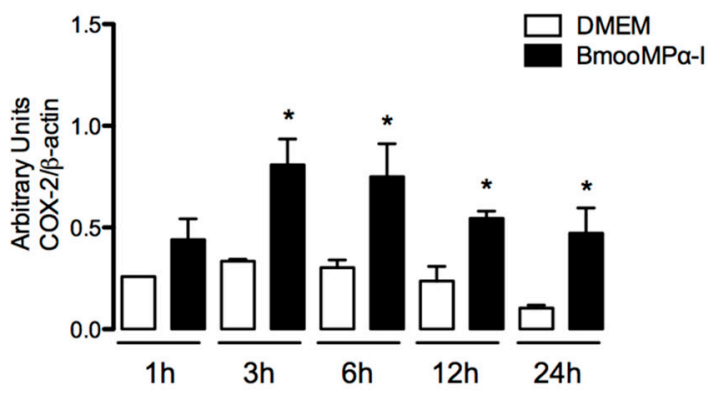

Figure 2. BmooMP $\alpha$-I activates $\mathrm{COX}-1$ and $\mathrm{COX}-2$ pathways to release $\mathrm{PGE}_{2}$ and upregulates COX-2 protein expression: (A) cultured preadipocytes were pretreated with the selective inhibitors of COX-1, COX-2, SC-560, and NS-398 for $1 \mathrm{~h}$ and incubated with BmooMP $\alpha-\mathrm{I}(0.24 \mu \mathrm{M})$ or DMEM (control) for $12 \mathrm{~h}$, then supernatants were collected and PGE 2 was quantified by ELISA; (B-E) preadipocytes were incubated with BmooMP $\alpha$-I $(0.24 \mu \mathrm{M})$ (Bmoo) or DMEM (control) for 1, 3, 6, 12, and $24 \mathrm{~h}$; (B) representative Western blotting of COX-1 and $\beta$-actin (loading control) showing immunoreactive bands; (D) representative Western blotting of COX-2 and $\beta$-actin (loading control) showing immunoreactive bands; densitometric analysis of immunoreactive (C) COX-1 and (E) COX-2 bands. Data are means \pm SEM of 4 samples. Note: ${ }^{*} p<0.05$ relative to control; ${ }^{\#} p<0.05$ relative to BmooMP $\alpha$-I (with vehicle); (A) one-way ANOVA and Bonferroni post-test; (C,E) two-way ANOVA and Bonferroni post-test.

\section{5. $c P L A_{2}-\alpha$ and sPLA $A_{2}$-IIA Participate in the BmooMP $\alpha$-I-Induced Release of PGE $E_{2}$}

It is well known that $\mathrm{PLA}_{2} \mathrm{~S}$ are upstream enzymes in the signalling cascade involved in the production of eicosanoids, including PGs. Additionally, it is well documented that $\mathrm{PLA}_{2} \mathrm{~S}$ hydrolyse membrane phospholipids, resulting in the release of $\mathrm{AA}$, which is further converted into biologically active PGs, such as $\mathrm{PGE}_{2}$, by the COX enzymes and PG synthases [66]. Taking this information into account, we investigated the role of distinct $\mathrm{PLA}_{2} \mathrm{~S}$ in $\mathrm{PGE}_{2}$ release induced by $\mathrm{BmooMP} \alpha$-I. We used pharmacological approaches to identify the critical $\mathrm{PLA}_{2} \mathrm{~S}$ involved in this effect of BmooMP $\alpha$-I. For this purpose, cells were pretreated with effective concentrations of PYR-2 compound, a specific inhibitor of cPLA $_{2}-\alpha$; FKGK11 compound, an inhibitor of iPLA 2 ; or KH064 compound, a sPLA 2 -IIA 
inhibitor. As marked release of $\mathrm{PGE}_{2}$ was detected after $12 \mathrm{~h}$ of incubation with $\mathrm{BmooMP} \alpha-$ I, we evaluated the effects of the pharmacological compounds in the same time interval. As shown in Figure 5, the treatment of cells with PYR-2 or KH064 compounds abolished the stimulatory effect of BmooMP $\alpha$-I in comparison with the positive control. The treatment of cells with FKGK11 compound, however, did not affect the release of PGE $_{2}$ induced by this metalloproteinase. These findings indicate that $\mathrm{CPLA}_{2}-\alpha$ and $\mathrm{SPLA}_{2}$-IIA but not iPLA 2 are involved in the production of $\mathrm{PGE}_{2}$ induced by BmooMP $\alpha-\mathrm{I}$ in preadipocytes.

A

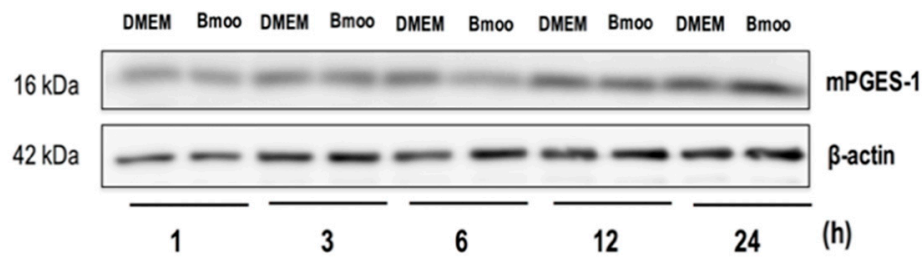

B

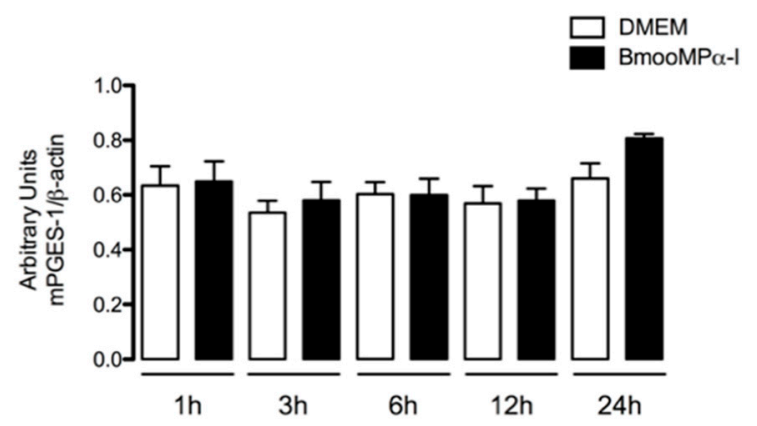

Figure 3. BmooMP $\alpha$-I does not alter mPGES-1 protein expression in preadipocytes. Preadipocytes were incubated with BmooMP $\alpha-\mathrm{I}(0.24 \mu \mathrm{M})(\mathrm{Bmoo})$ or DMEM (control) for 1, 3, 6, 12, and $24 \mathrm{~h}$ : (A) representative Western blotting of mPGES-1 and $\beta$-actin (loading control) showing immunoreactive bands; (B) densitometric analysis of immunoreactive mPGES-1 bands. Densities (in arbitrary units) were normalized to $\beta$-actin densities. Results are expressed as means \pm SEM of 4 samples.

\subsection{BmooMP $\alpha-I$ Induces Release of MCP-1 and Adiponectin by Cultured Preadipocytes}

Cytokines and adipokines are important mediators that participate in the development of inflammatory diseases and in adipose tissue inflammation [67-71]. To further investigate the inflammatory effects of MMPs in preadipocytes, we evaluated whether BmooMP $\alpha-\mathrm{I}$ can induce the release of cytokines and adipokines by these cells. Thus, preadipocytes were incubated with $\mathrm{BmooMP} \alpha-\mathrm{I}(0.24 \mu \mathrm{M})$ for $1,3,6,12,24$, or $48 \mathrm{~h}$, and the release of those mediators was evaluated by ELISA. As shown in Figure 6, BmooMP $\alpha$-I induced significant release of MCP-1 from 3 to $24 \mathrm{~h}$ (Figure 6A) and of adiponectin (about 80\% increase) at $48 \mathrm{~h}$ of incubation (Figure 6D) when compared with control cells incubated with culture medium alone. This metalloproteinase did not induce significant release of IL-6 (Figure 6B), KC (Figure 6C), leptin (Figure 6E), or resistin (Figure 6F) compared with control cells. The release of TNF- $\alpha$, IL-1 $\beta$, and IL-10 was not detectable in our experimental condition. The obtained results show for the first time the capacity of a metalloproteinase to induce release of MCP-1 and adiponectin by preadipocytes and are in line with the reported proinflammatory activity of MMPs and SVMPS, especially BmooMP $\alpha$-I. 
A

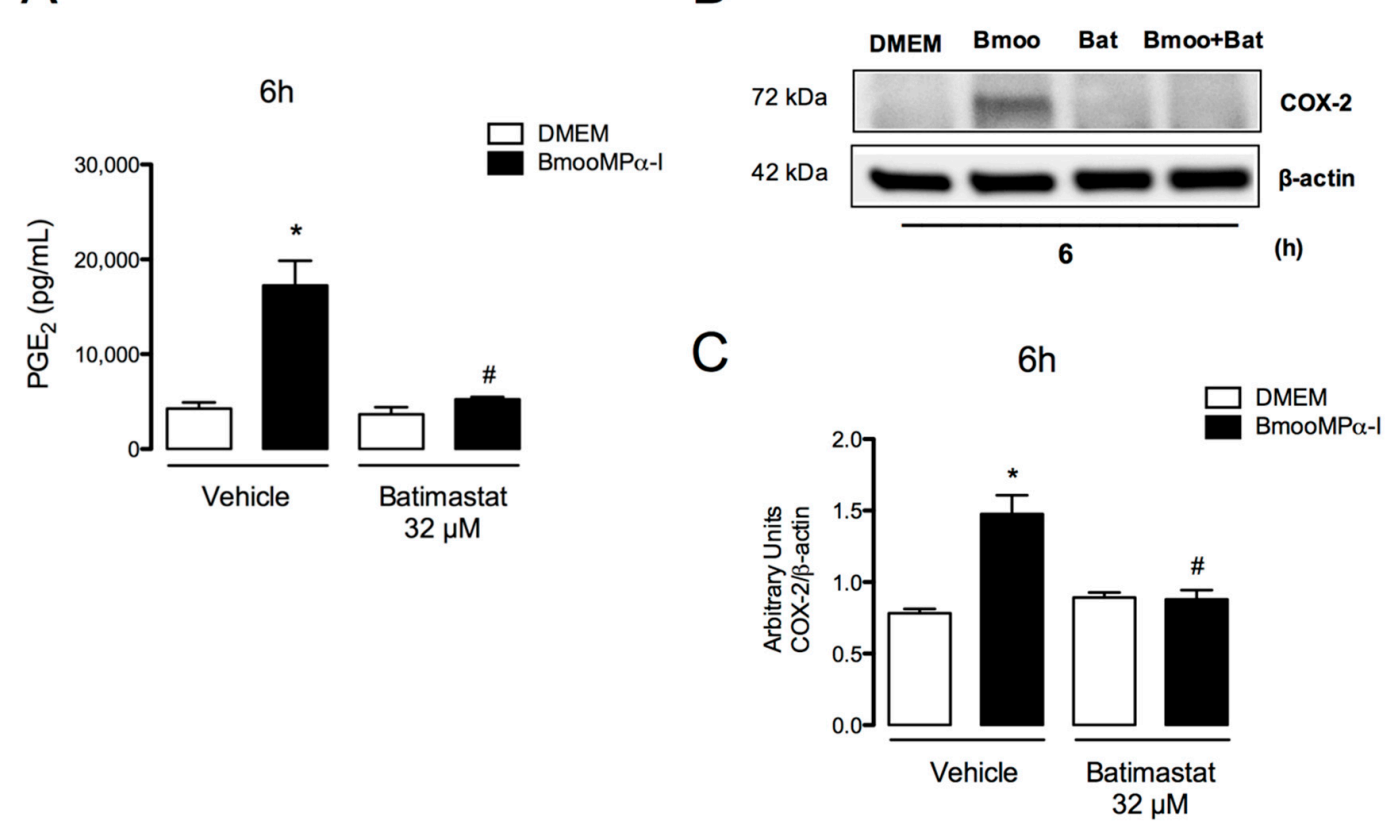

Figure 4. BmooMP $\alpha$-I-induced release of $\mathrm{PGE}_{2}$ and COX-2 expression are dependent on metalloproteinase enzymatic activity. Cultured preadipocytes were incubated with BmooMP $\alpha-\mathrm{I}(0.24 \mu \mathrm{M})(\mathrm{Bmoo})$, Batimastat (Bat), BmooMP $\alpha$-I + Batimastat, or vehicle (DMSO) for $6 \mathrm{~h}$ : (A) concentration of $\mathrm{PGE}_{2}$ present in culture supernatant was quantified by ELISA; (B) representative Western blotting of COX-2 and $\beta$-actin (loading control) showing immunoreactive bands; (C) densitometric analysis of immunoreactive COX-2 bands. Densities (in arbitrary units) were normalized to $\beta$-actin densities. Results are expressed as means \pm SEM of 4 samples. Note: ${ }^{*} p<0.05$ relative to control; ${ }^{\#} p<0.05$ relative to BmooMP $\alpha$-I (with vehicle) (one-way ANOVA, Bonferroni post-test).

\section{$12 \mathrm{~h}$}

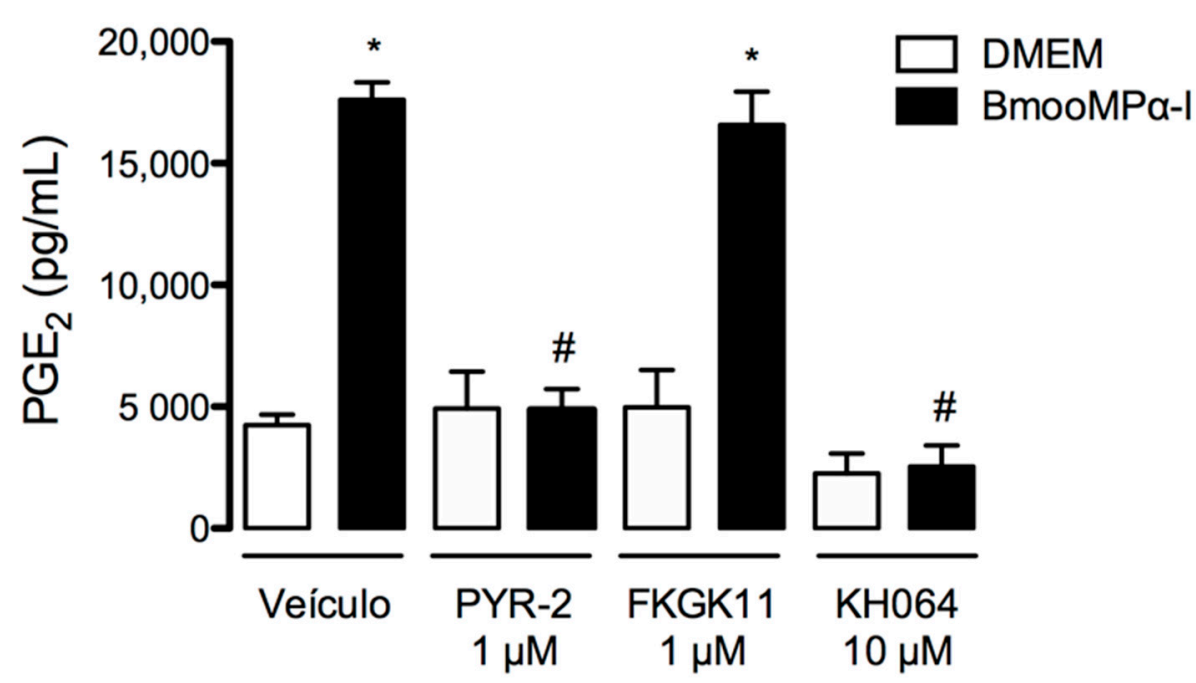

Figure 5. Both cPLA2- $\alpha$ and sPLA 2 -IIA are involved in the release of $\mathrm{PGE}_{2}$ induced by BmooMP $\alpha$-I. Cultured preadipocytes were pretreated with PYR-2, cPLA $2-\alpha$ inhibitor, FKGK11, iPLA 2 inhibitor, KH064, sPLA 2 -IIA inhibitor, or DMEM + vehicle (DMSO $<1 \%$ ) for $1 \mathrm{~h}$ and then stimulated with $\operatorname{BmooMP} \alpha-\mathrm{I}(0.24 \mu \mathrm{M})$ for $12 \mathrm{~h}$. Supernatants were collected and the concentration of $\mathrm{PGE}_{2}$ was quantified by ELISA. Each value represents the mean \pm SEM of 3 samples. Note: ${ }^{*} p<0.05$ vs. control; ${ }^{\#} p<0.05$ vs. BmooMP $\alpha$-I (one-way ANOVA, Bonferroni post-test). 
A

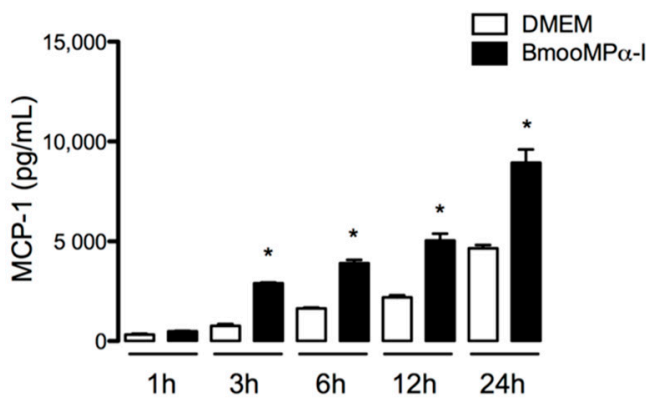

B

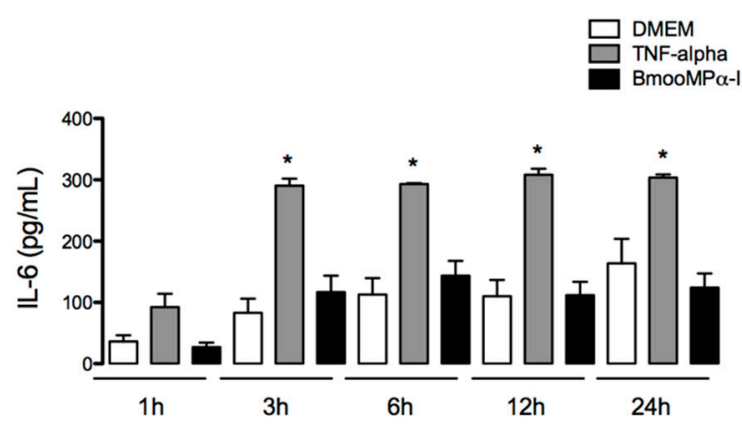

C

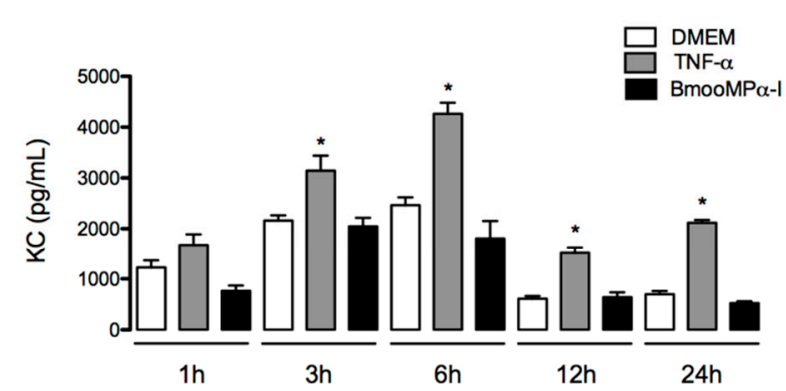

D

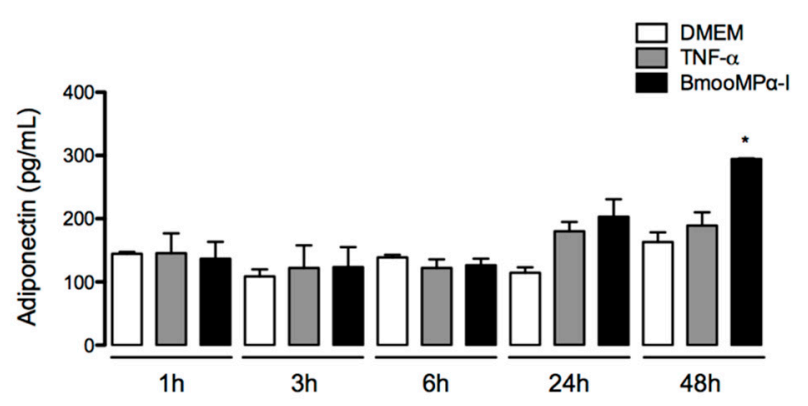

E

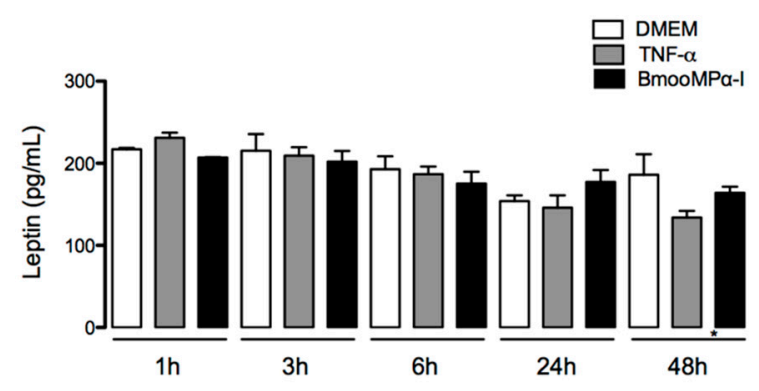

$\mathrm{F}$

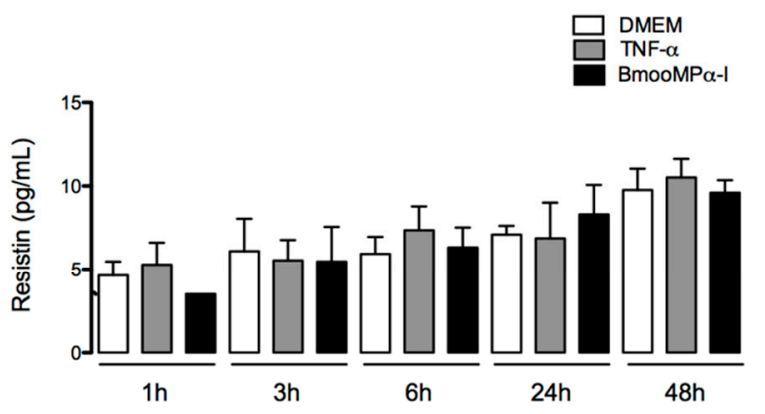

Figure 6. BmooMP $\alpha$-I induces the release of MCP-1 and adiponectin by preadipocytes. Preadipocytes were incubated with BmooMP $\alpha$-I $(0.24 \mu \mathrm{M})$, TNF-alpha (20 ng/mL-positive control), or DMEM (control) for 1, 3, 6, 12, 24, or 48. Concentrations of cytokines in culture supernatants were determined by CBA and adipokines were quantified by ELISA. Bar graphs show the release of (A) MCP-1, (B) IL-6, (C) KC, (D) adiponectin, (E) leptin and (F) resistin. Each value represents the mean \pm SEM of 3 samples. Note: ${ }^{*} p<0.05$ vs. control (one-way ANOVA, Bonferroni post-test).

\section{Discussion}

Matrix metalloproteinases have been associated with the pathogenesis of various inflammation-related diseases, ranging from cancer to chronic inflammatory diseases, including obesity [1,3,5-9]. Levels of MMPs are elevated in the adipose tissue of obese patients [6] but the inflammatory effects of MMPs in this tissue are not fully understood. Comprehending the inflammatory action of metalloproteinases on adipose tissue cells, such as preadipocytes, is critical to identify the factors underlying adipose tissue inflammation, which lead to obesity or inflammation of adjacent tissues due to the impacts of inflammatory mediators reaching these tissues [68]. We have demonstrated the ability of $\operatorname{BmooMP} \alpha-\mathrm{I}$, a P-I class SVMP, to elicit an inflammatory response in preadipocytes in culture. Our results 
show that $\mathrm{BmooMP} \alpha-\mathrm{I}$ induced a marked release of $\mathrm{PGE}_{2}$ and $\mathrm{PGI}_{2}$ from preadipocytes in culture. The concentrations of $\mathrm{BmooMP} \alpha-\mathrm{I}$ able to induce release of these prostaglandins were comparable to those described for relevant MMPs, such as MMP-2, in the plasma of obese patients [6]; therefore, it is plausible to suggest that $\mathrm{PGE}_{2}$ and $\mathrm{PGI}_{2}$ can mediate the inflammatory actions of metalloproteinases in the adipose tissue and exert paracrine actions in structures adjacent to this tissue, contributing to the development of distinct inflammatory conditions, such as arthropathies [18,23]. Although the ability of MMP-1 and MMP-3 to release $\mathrm{PGE}_{2}$ from isolated macrophages and of an SVMP, $\mathrm{BaP1}$, to release this mediator by fibroblast-like synoviocytes $[61,72]$ has previously been reported, to our knowledge this is the first report providing evidence of a metalloproteinase inducing the production of $\mathrm{PGE}_{2}$ and $\mathrm{PGI}_{2}$ by adipose tissue cells.

Prostanoids are produced from the metabolism of AA by COX- 1 and COX-2 and are fundamental mediators in inflammatory responses and the perpetuation of inflammation signs and symptoms $[60,73]$. In the adipose tissue, prostanoids, mainly $\mathrm{PGE}_{2}$, are implicated in the process of the differentiation of preadipocytes into mature adipocytes, leading to the increased mass of this tissue [25,28,74-76]. Taking into account the marked release of $\mathrm{PGE}_{2}$ in preadipocytes stimulated by BmooMP $\alpha-\mathrm{I}$ and the importance of this mediator in inflammation, we investigated the mechanisms involved in $\mathrm{PGE}_{2}$ biosynthesis induced by BmooMP $\alpha$-I. Our findings from our pharmacological approach showed that $\mathrm{PGE}_{2}$ production induced by BmooMP $\alpha-\mathrm{I}$ is dependent on the activation of COX- 1 and COX-2 isoforms in preadipocytes. As an additional mechanism, $\mathrm{BmooMP} \alpha$-I upregulated COX-2 protein expression but did not alter the protein levels of the inducible terminal synthase mPGES-1. As expected, BmooMP $\alpha$-I did not affect protein expression of the constitutive COX-1. These results indicate that adipose tissue cells are targets for the action of metalloproteinases and align with the idea that COX-derived mediators can be second messengers of metalloproteinases for the development of inflammation in these cells. The mechanism by which BmooMP $\alpha-\mathrm{I}$ upregulates the expression of COX-2 in preadipocytes has not yet been investigated. However, an autocrine effect of the chemokine MCP-1 may be involved in this effect, since this mediator is released from preadipocytes upon BmooMP $\alpha$-I stimulus and has been previously reported to lead to COX-2 expression [76-78].

$\mathrm{PLA}_{2} \mathrm{~S}$ are lipolytic enzymes that act on membrane glycerophospholipids for the release of AA, the main substrate of COX enzymes and the precursor of PGs, including $\mathrm{PGE}_{2}$. $\mathrm{PLA}_{2} \mathrm{~S}$ have also been demonstrated to be key enzymes in triggering diverse inflammatory diseases [79-83]. In this work, we investigated the participation of these enzymes in the BmooMP $\alpha$-I-induced release of $\mathrm{PGE}_{2}$. Our results, which showed that the pharmacological inhibition of cytosolic PLA $\mathrm{S}_{2} \mathrm{~s}$ or group-IIA-secreted $\mathrm{PLA}_{2} \mathrm{~S}$ markedly reduced the BmooMP $\alpha$-I-induced release of $\mathrm{PGE}_{2}$, indicated that both cytosolic and group-IIA-secreted $\mathrm{PLA}_{2} \mathrm{~S}$ are important players in the generation of $\mathrm{PGE}_{2}$ following BmooMP $\alpha$-I stimulus. These findings are evidence of a link between metalloproteinases and $\mathrm{PLA}_{2} \mathrm{~s}$, by which the venom metalloproteinase stimulates preadipocytes to produce $\mathrm{PGE}_{2}$; they are in accordance with previous studies demonstrating a link between metalloproteinases and $\mathrm{PLA}_{2}$ for the production of $\mathrm{PGE}_{2}$ by fibroblast-like synoviocytes [72]. On the other hand, a negative regulation of a cardiac sPLA 2 by MMP-2 in a proinflammatory setting has been previously reported, since in MMP-2 deficient mice the production and release of a unique SPLA $\mathrm{A}_{2}$ was increased in cardiomyocytes [84,85]; thus, MMPs may act as modulators of distinct members of the $\mathrm{PLA}_{2}$ family and may regulate inflammation signaling, both when expressed in excess and when underexpressed. The mechanisms involved in BmooMP $\alpha$-I-induced activation of $\mathrm{CPLA}_{2}-\alpha$ and sPLA $\mathrm{S}_{2}$-IIA were not addressed in our study; however, in the case of $\mathrm{cPLA}_{2}-\alpha$, some mechanisms may be suggested. First, the release of molecular patterns associated with cell damage (DAMPs) via the action of BmooMP $\alpha$-I on cell membrane may lead to activation of Toll-like receptors (TLR) followed by production of inflammatory mediators, including $\mathrm{PGE}_{2}$. In this context, the regulation of $\mathrm{CPLA}_{2}$ activation and lipid generation by TLR4 signaling [86] and activation of TLR4 by DAMPs [87] were previously reported. Moreover, production of DAMPS by a snake venom metalloproteinase and 
MMPs were recently demonstrated $[86,88]$. Second, the potential activation of PAR receptor by BmooMP $\alpha$-I may result in increased phosphorylation of $\mathrm{CPLA}_{2}$ and the release of AA, since activation of the PAR receptor by proteases leading to activation of $\mathrm{CPLA}_{2}-\alpha$ coupled to COX-1 has been reported [89].

In addition, our results showing that the inhibition of the $B m o o M P \alpha-I$ catalytic domain abolished $\mathrm{PGE}_{2}$ release and COX-2 protein expression indicate that the catalytic activity of BmooMP $\alpha$-I is essential for the activation of the biosynthetic pathway for the production of prostanoids in preadipocytes. Considering that the catalytic domain of metalloproteinases was demonstrated to be responsible for the degradation of ECM components and for the processing of non-matrix proteins, such as cytokines, chemokines, and receptors [11,72], our findings provide insight into the role of the catalytic domain of MMPs in the release of lipid mediators triggered by this class of enzymes.

Extensive research has shown that the inflammation of adipose tissue may be a major factor in the development of metabolic diseases and that cytokines and adipokines released by adipose tissue contribute to the inflammation of adjacent tissues $[18,23,76,90]$. Our results showing that $\mathrm{BmooMP} \alpha-\mathrm{I}$ induced a marked release of MCP- 1 and a late release of adiponectin from preadipocytes in culture contribute to the information regarding the inflammatory effects of this metalloproteinase on preadipocytes. It is known that MCP-1 initiates adipose tissue inflammation by inducing the recruitment of monocytes to the tissue, contributing to obesity onset [35,71]. Moreover, MCP-1 biosynthesis has been reported in the intra-articular adipose tissue, with a role in the pathogenesis of joint diseases [91]; thus, the release of MCP-1 by preadipocytes under the stimulus of a metalloproteinase may contribute not only to adipose tissue inflammation, but also to the progression of inflammation in adjacent tissues. Moreover, a role of MCP-1 in activation of $\mathrm{PLA}_{2} \mathrm{~s}$ induced by $\mathrm{BmooMP} \alpha$-I may be suggested, since MCP-1 has been shown to induce the phosphorylation of $\mathrm{CPLA}_{2}-\alpha$ and the rapid release of AA by human leukocytes [92,93]. Adiponectin is mainly produced by the adipose tissue and has been recognised as an important modulator of the immune system [69]. Unlike most other adipokines, adiponectin appears to have a protective role in metabolic syndrome and diabetes mellitus type $2[69,70]$. However, in inflammatory joint diseases, this adipokine has been highlighted as an important player in synovitis and joint destruction, as it acts as a proinflammatory mediator, inducing the production of MCP-1, $\mathrm{PGE}_{2}$, and MMPs and the expression of COX-2 by synovial cells $[23,69,77]$; thus, the release of adiponectin by preadipocytes under the stimulus of a metalloproteinase provides insight into the participation of MMPs and adipose tissue cells in joint inflammation. In addition, it is possible to suggest that via autocrine signalling, adiponectin amplifies the release of MCP-1 and $\mathrm{PGE}_{2}$ and COX-2 expression by preadipocytes under the stimulus of a metalloproteinase. To our knowledge, this is the first demonstration of the ability of a metalloproteinase to trigger adiponectin and MCP-1 synthesis by adipose tissue cells.

In conclusion, the data from the present study show, for the first time, the ability of a representative single-domain metalloproteinase, $\operatorname{BmooMP} \alpha$-I, to activate an inflammatory response in preadipocytes. BmooMP $\alpha$-I induced the release of the inflammatory mediators $\mathrm{PGE}_{2}, \mathrm{PGI}_{2}, \mathrm{MCP}-1$, and adiponectin but not IL-6, KC, leptin, or resistin by preadipocytes. BmooMP $\alpha$-I-induced PGE 2 biosynthesis was dependent on sPLA 2 -IIA, $\mathrm{CPLA}_{2}-\alpha, \mathrm{COX}-1$, and COX-2 pathways. Moreover, BmooMP $\alpha$-I upregulated COX-2 protein expression but did not alter mPGES-1 expression. Furthermore, we demonstrated that BmooMP $\alpha$-I enzymatic activity is essential for the activation of prostanoid biosynthesis in preadipocytes (Scheme 1). Altogether, our data highlight preadipocytes as important targets for the action of metalloproteinases and provide new insights into the contributions of these enzymes to the inflammation of adipose tissue and tissues adjacent to it. Furthermore, our study provides insight into the importance of the catalytic domain of MMPs to the inflammatory activity triggered by these enzymes. 


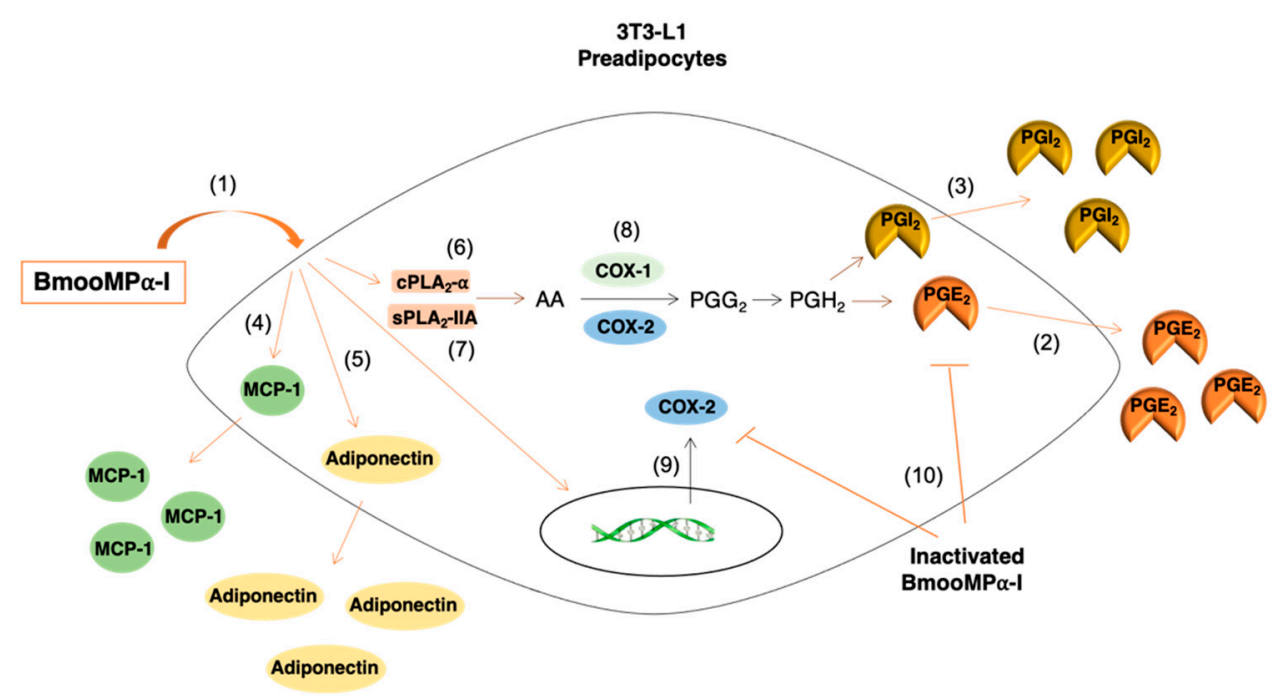

Scheme 1. Inflammatory pathway activated by BmooMP $\alpha$-I in 3T3-L1 preadipocytes. (1) BmooMP $\alpha$-I activates preadipocytes to release (2) $\mathrm{PGE}_{2}$, (3) $\mathrm{PGI}_{2}$, (4) MCP-1, and (5) adiponectin. The biosynthesis of $\mathrm{PGE}_{2}$ induced by BmooMP $\alpha-\mathrm{I}$ is dependent on the actions of (6) $\mathrm{CPLA}_{2}-\alpha$ and (7) group IIA sPLA 2 , and on the (8) COX-1 and COX-2 pathways. (9) BmooMP $\alpha$-I upregulates protein expression of COX-2. (10) The enzymatic activity of BmooMP $\alpha$-I is essential for the biosynthesis of $\mathrm{PGE}_{2}$ and protein expression of COX-2 in 3T3-L1 preadipocytes.

Author Contributions: Conceptualization, P.M.J., E.L. and C.T.; methodology, E.L. and P.M.J.; formal analysis, P.M.J. and E.L.; investigation, P.M.J. and E.L.; isolation and purification of BmooMP $\alpha-\mathrm{I}$, V.P.; writing-original draft preparation, P.M.J., E.L. and C.T.; writing-review and editing P.M.J., E.L. and C.T.; supervision, C.T.; project administration, C.T. All authors have read and agreed to the published version of the manuscript.

Funding: São Paulo Research Foundation (FAPESP) and GlaxoSmithKline (GSK) funded this research, grant 2015/50040-4. P.M.J. is a recipient of a fellowship from FAPESP (grant 2017/197339). E.L. is a recipient of a post-doc fellowship from Coordenação de Aperfeiçoamento de Pessoal de Nível Superior (CAPES). C.T. is a recipient of a Conselho Nacional de Desenvolvimento Científico e Tecnológico fellowship (PQ-CNPq), grant number 310930/2019-7, and of Fundação Butantan, 2019-2021.

Acknowledgments: The authors thank Cristina Maria Fernandes (Laboratório de Farmacologia, Instituto Butantan, Brazil) and Mariana Nascimento Viana (Laboratório de Farmacologia, Instituto Butantan, Brazil) for their valuable advice and discussions; and Renata Hage do Amaral Hernandez (Laboratório de Farmacologia, Instituto Butantan, Brazil) for providing technical assistance. The authors also thank Giselle Pidde Queiroz and Denise Vilarinho Tambourgi (Laboratório de Imunoquímica, Instituto Butantan, Brazil) for the evaluation of the enzymatic activity of BmooMP $\alpha$-I and the use of laboratory facilities (Grant FAPESP/CETICS 2013/07467-1).

Conflicts of Interest: The authors declare no conflict of interest.

\section{References}

1. Nissinen, L.; Kähäri, V.M. Matrix metalloproteinases in inflammation. Biochim. Biophys. Acta Gen. Subj. 2014, 1840, 2571-2580. [CrossRef]

2. Cui, N.; Hu, M.; Khalil, R.A. Biochemical and Biological Attributes of Matrix Metalloproteinases. Prog. Mol. Biol. Transl. Sci. 2017, 147, 1-73. [PubMed]

3. Fingleton, B. Matrix metalloproteinases as regulators of inflammatory processes. Biochim. Biophys. Acta Mol. Cell Res. 2017, 1864, 2036-2042. [CrossRef]

4. Woessner, J.F. Matrix metalloproteinases and their inhibitors in connective tissue remodeling. FASEB J. 1991, 5, $2145-2154$. [CrossRef]

5. Grzechocińska, B.; Dąbrowski, F.; Sierdzinski, J.; Cyganek, A.; Wielgoś, M. The association between serum metalloproteinase concentration, obesity, and hormone levels in reproductive-aged women. Endokrynol. Pol. 2019, 70, 49-53. [CrossRef] [PubMed] 
6. Derosa, G.; Ferrari, I.; D'Angelo, A.; Tinelli, C.; Salvadeo, S.A.T.; Ciccarelli, L.; Piccinni, M.N.; Gravina, A.; Ramondetti, F.; Maffioli, P.; et al. Matrix Metalloproteinase-2 and -9 Levels in Obese Patients. Endothel. J. Endothel. Cell Res. 2008, 15, 219-224. [CrossRef] [PubMed]

7. Jaoude, J.; Koh, Y. Matrix metalloproteinases in exercise and obesity. Vasc. Health Risk Manag. 2016, 12, 287-295. [CrossRef]

8. Hannocks, M.J.; Zhang, X.; Gerwien, H.; Chashchina, A.; Burmeister, M.; Korpos, E.; Song, J.; Sorokin, L. The gelatinases, MMP-2 and MMP-9, as fine tuners of neuroinflammatory processes. Matrix Biol. 2019, 75-76, 102-113. [CrossRef]

9. Malemud, C.J. Matrix metalloproteinases (MMPs) in health and disease: An overview. Front. Biosci. 2006, 11, 1696-1701. [CrossRef]

10. Mohammed, F.F.; Smookler, D.S.; Khokha, R. Metalloproteinases, inflammation, and rheumatoid arthritis. Ann. Rheum. Dis. 2003, 62, 43-47. [CrossRef]

11. Parks, W.C.; Wilson, C.L.; López-Boado, Y.S. Matrix metalloproteinases as modulators of inflammation and innate immunity. Nat. Rev. Immunol. 2004, 4, 617-629. [CrossRef]

12. Lauhio, A.; Färkkilä, E.; Pietiläinen, K.H.; Åström, P.; Winkelmann, A.; Tervahartiala, T.; Pirilä, E.; Rissanen, A.; Kaprio, J.; Sorsa, T.A.; et al. Association of MMP-8 with obesity, smoking and insulin resistance. Eur. J. Clin. Investig. 2016, 46, 757-765. [CrossRef] [PubMed]

13. Catalán, V.; Gómez-Ambrosi, J.; Rodríguez, A.; Ramírez, B.; Silva, C.; Rotellar, F.; Gil, M.J.; Cienfuegos, J.A.; Salvador, J.; Frühbeck, G. Increased adipose tissue expression of lipocalin-2 in obesity is related to inflammation and matrix metalloproteinase-2 and metalloproteinase-9 activities in humans. J. Mol. Med. 2009, 87, 803-813. [CrossRef] [PubMed]

14. Bouloumié, A.; Sengenès, C.; Portolan, G.; Galitzky, J.; Lafontan, M. Adipocyte Produces Matrix Metalloproteinases 2 and 9 Involvement in Adipose Differentiation. Diabetes 2001, 50, 2080-2086. [CrossRef] [PubMed]

15. Chavey, C.; Mari, B.; Monthouel, M.N.; Bonnafous, S.; Anglard, P.; Van Obberghen, E.; Tartare-Deckert, S. Matrix metalloproteinases are differentially expressed in adipose tissue during obesity and modulate adipocyte differentiation. J. Biol. Chem. 2003, 278, 11888-11896. [CrossRef]

16. Shih, C.L.M.; Ajuwon, K.M. Inhibition of MMP-13 prevents diet-induced obesity in mice and suppresses adipogenesis in 3T3-L1 preadipocytes. Mol. Biol. Rep. 2015, 42, 1225-1232. [CrossRef]

17. Kontny, E.; Plebanczyk, M.; Lisowska, B.; Olszewska, M.; Maldyk, P.; Maslinski, W. Comparison of rheumatoid articular adipose and synovial tissue reactivity to proinflammatory stimuli: Contribution to adipocytokine network. Ann. Rheum. Dis. 2012, 71, 262-267. [CrossRef]

18. Clockaerts, S.; Bastiaansen-Jenniskens, Y.M.; Runhaar, J.; Van Osch, G.J.V.M.; Van Offel, J.F.; Verhaar, J.A.N.; De Clerck, L.S.; Somville, J. The infrapatellar fat pad should be considered as an active osteoarthritic joint tissue: A narrative review. Osteoarthr. Cartil. 2010, 18, 876-882. [CrossRef]

19. Oikonomou, E.K.; Antoniades, C. The role of adipose tissue in cardiovascular health and disease. Nat. Rev. Cardiol. 2019, 16, 83-99. [CrossRef] [PubMed]

20. García-Alonso, V.; Titos, E.; Alcaraz-Quiles, J.; Rius, B.; Lopategi, A.; López-Vicario, C.; Jakobsson, P.J.; Delgado, S.; Lozano, J.; Clària, J. Prostaglandin E2 exerts multiple regulatory actions on human obese adipose tissue remodeling, inflammation, adaptive thermogenesis and lipolysis. PLoS ONE 2016, 11, e0153751. [CrossRef] [PubMed]

21. Maury, E.; Brichard, S.M. Adipokine dysregulation, adipose tissue inflammation and metabolic syndrome. Mol. Cell. Endocrinol. 2010, 314, 1-16. [CrossRef]

22. Juge-Aubry, C.E.; Henrichot, E.; Meier, C.A. Adipose tissue: A regulator of inflammation. Best Pract. Res. Clin. Endocrinol. Metab. 2005, 19, 547-566. [CrossRef] [PubMed]

23. Francisco, V.; Ruiz-Fernández, C.; Pino, J.; Mera, A.; González-Gay, M.A.; Gómez, R.; Lago, F.; Mobasheri, A.; Gualillo, O. Adipokines: Linking metabolic syndrome, the immune system, and arthritic diseases. Biochem. Pharmacol. 2019, 165, 196-206. [CrossRef]

24. Nasrallah, R.; Hassouneh, R.; Hébert, R.L. PGE2, kidney disease, and cardiovascular risk: Beyond hypertension and diabetes. J. Am. Soc. Nephrol. 2016, 27, 666-676. [CrossRef]

25. Xu, H.; Fu, J.L.; Miao, Y.F.; Wang, C.J.; Han, Q.F.; Li, S.; Huang, S.Z.; Du, S.N.; Qiu, Y.X.; Yang, J.C.; et al. Prostaglandin E2 receptor EP3 regulates both adipogenesis and lipolysis in mouse white adipose tissue. J. Mol. Cell Biol. 2016, 8, 518-529. [CrossRef] [PubMed]

26. Akaogi, J.; Nozaki, T.; Satoh, M.; Yamada, H. Role of PGE2 and EP Receptors in the Pathogenesis of Rheumatoid Arthritis and as a Novel Therapeutic Strategy. Endocr. Metab. Immune Disord.-Drug Targets 2012, 6, 383-394. [CrossRef]

27. Brouwers, H.; Von Hegedus, J.; Toes, R.; Kloppenburg, M.; Ioan-Facsinay, A. Lipid mediators of inflammation in rheumatoid arthritis and osteoarthritis. Best Pract. Res. Clin. Rheumatol. 2015, 29, 741-755. [CrossRef]

28. García-Alonso, V.; Clária, J. Prostaglandin E 2 signals white-to-brown adipogenic differentiation. Adipocyte 2014, 3, 290-296. [CrossRef]

29. Kimple, M.E.; Keller, M.P.; Rabaglia, M.R.; Pasker, R.L.; Neuman, J.C.; Truchan, N.A.; Brar, H.K.; Attie, A.D. Prostaglandin E2 receptor, EP3, is induced in diabetic islets and negatively regulates glucose- and hormone- stimulated insulin secretion. Diabetes 2013, 62, 1904-1912. [CrossRef] [PubMed]

30. Fain, J.N.; Bahouth, S.W. Regulation of leptin release by mammalian adipose tissue. Biochem. Biophys. Res. Commun. 2000, 274, 571-575. [CrossRef] 
31. Osborn, O.; Gram, H.; Zorrilla, E.P.; Conti, B.; Bartfai, T. Insights into the roles of the inflammatory mediators IL-1, IL-18 and PGE2 in obesity and insulin resistance. Swiss Med. Wkly. 2008, 138, 665-673. [CrossRef]

32. Engin, A.B.; Engin, A. Obesity and Lipotoxicity; Springer: Berlin, Germany, 2017; Volume 960. [CrossRef]

33. Stolarczyk, E. Adipose tissue inflammation in obesity: A metabolic or immune response? Curr. Opin. Pharmacol. 2017, 37, 35-40. [CrossRef] [PubMed]

34. Iyer, A.; Fairlie, D.P.; Prins, J.B.; Hammock, B.D.; Brown, L. Inflammatory lipid mediators in adipocyte function and obesity. Nat. Rev. Endocrinol. 2010, 6, 71-82. [CrossRef]

35. Dordevic, A.L.; Konstantopoulos, N.; Cameron-Smith, D. 3T3-L1 preadipocytes exhibit heightened monocyte-chemoattractant protein-1 response to acute fatty acid exposure. PLoS ONE 2014, 9, e99382. [CrossRef]

36. Guo, W.; Wong, S.; Xie, W.; Lei, T.; Luo, Z. Palmitate modulates intracellular signaling, induces endoplasmic reticulum stress, and causes apoptosis in mouse 3T3-L1 and rat primary preadipocytes. Am. J. Physiol. Endocrinol. Metab. 2007, 293, E576-E586. [CrossRef]

37. Chung, S.; LaPoint, K.; Martinez, K.; Kennedy, A.; Sandberg, M.B.; McIntosh, M.K. Preadipocytes mediate lipopolysaccharideinduced inflammation and insulin resistance in primary cultures of newly differentiated human adipocytes. Endocrinology 2006, 147, 5340-5351. [CrossRef] [PubMed]

38. Lijnen, H.R. Murine models of obesity and hormonal therapy. Thromb. Res. 2011, 127, S17-S20. [CrossRef]

39. Bauters, D.; Van Hul, M.; Lijnen, H.R. Macrophage elastase (MMP-12) in expanding murine adipose tissue. Biochim. Biophys. Acta Gen. Subj. 2013, 1830, 2954-2959. [CrossRef] [PubMed]

40. Van Hul, M.; Bauters, D.; Lijnen, R.H. Differential effects of a gelatinase inhibitor on adipocyte differentiation and adipose tissue development. Clin. Exp. Pharmacol. Physiol. 2013, 40, 689-697. [CrossRef]

41. Bode, W.; Gomis-Rüth, F.X.; Stöckler, W. Astacins, serralysins, snake venom and matrix metalloproteinases exhibit identical zinc-binding environments (HEXXHXXGXXH and Met-turn) and topologies and should be grouped into a common family, the "metzincins". FEBS Lett. 1993, 331, 134-140. [CrossRef]

42. Camacho, E.; Sanz, L.; Escalante, T.; Pérez, A.; Villalta, F.; Lomonte, B.; Neves-Ferreira, A.G.C.; Feoli, A.; Calvete, J.J.; Gutiérrez, J.M.; et al. Novel catalytically-inactive PII metalloproteinases from a viperid snake venom with substitutions in the canonical zinc-binding motif. Toxins 2016, 8, 292. [CrossRef]

43. Parks, W.C. Matrix Metalloproteinases. Encycl. Respir. Med. Four Vol. Set 2006, 18-25. [CrossRef]

44. Fox, J.W.; Serrano, S.M.T. Insights into and speculations about snake venom metalloproteinase (SVMP) synthesis, folding and disulfide bond formation and their contribution to venom complexity. FEBS J. 2008, 275, 3016-3030. [CrossRef]

45. Bjarnason, J.B.; Fox, J.W. Snake venom metalloendopeptidases: Reprolysins. Methods Enzymol. 1995, 248, 345-368. [CrossRef] [PubMed]

46. Takeda, S.; Takeya, H.; Iwanaga, S. Snake venom metalloproteinases: Structure, function and relevance to the mammalian ADAM/ADAMTS family proteins. Biochim. Biophys. Acta Proteins Proteom. 2012, 1824, 164-176. [CrossRef]

47. Bernardes, C.P.; Santos-Filho, N.A.; Costa, T.R.; Gomes, M.S.R.; Torres, F.S.; Costa, J.; Borges, M.H.; Richardson, M.; dos Santos, D.M.; de Castro Pimenta, A.M.; et al. Isolation and structural characterization of a new fibrin(ogen)olytic metalloproteinase from Bothrops moojeni snake venom. Toxicon 2008, 51, 574-584. [CrossRef]

48. Pidde-Queiroz, G.; Magnoli, F.C.; Portaro, F.C.; Serrano, S.M.; Lopes, A.S.; Paes Leme, A.F.; van den Berg, C.W.; Tambourgi, D.V. P-I snake venom metalloproteinase is able to activate the complement system by direct cleavage of central components of the cascade. PLoS Negl. Trop. Dis. 2013, 7, e2519. [CrossRef] [PubMed]

49. Takayama, K.; Mitchell, D.H.; Din, Z.Z.; Mukerjee, P.; Li, C. Monomeric Re lipopolysaccharide from Escherichia coli is more active than the aggregated form in the Limulus amebocyte lysate assay and in inducing Egr-1 mRNA in murine peritoneal macrophages. J. Biol. Chem. 1994, 269, 2241-2244. [CrossRef]

50. Leiguez, E.; Zuliani, J.P.; Cianciarullo, A.M.; Fernandes, C.M.; Gutierrez, J.M.; Teixeira, C. A group IIA-secreted phospholipase A2 from snake venom induces lipid body formation in macrophages: The roles of intracellular phospholipases A2 and distinct signaling pathways. J. Leukoc. Biol. 2011, 90, 155-166. [CrossRef] [PubMed]

51. Nishimura, K.; Hatano, Y.; Setoyama, T.; Tsumagari, H.; Miyashita, K.; Lu, S.; Jisaka, M.; Nagaya, T.; Yokota, K. Control of Life Cycle of Mouse Adipogenic 3T3-L1 Cells. Appl. Biochem. Biotechnol. 2004, 118, 97-114. [CrossRef]

52. Nishimura, K.; Setoyama, T.; Tsumagari, H.; Miyata, N.; Hatano, Y.; Xu, L.; Jisaka, M.; Nagaya, T.; Yokota, K. Endogenous prostaglandins $\mathrm{E} 2$ and F2 $\alpha$ serve as an anti-apoptotic factor against apoptosis induced by tumor necrosis factor- $\alpha$ in mouse 3T3-L1 preadipocytes. Biosci. Biotechnol. Biochem. 2006, 70, 2145-2153. [CrossRef]

53. Sung, H.M.; Jenkins, C.M.; Mancuso, D.J.; Turk, J.; Gross, R.W. Smooth muscle cell arachidonic acid release, migration, and proliferation are markedly attenuated in mice null for calcium-independent phospholipase A2 $\beta$. J. Biol. Chem. 2008, 283, 33975-33987. [CrossRef]

54. Giannotti, K.C.; Leiguez, E.; Carvalho, A.; Galvão, N.; Matsubara, M.H.; Fortes-Dias, C.L.; Moreira, V.; Teixeira, C. A snake venom group IIA PLA2 with immunomodulatory activity induces formation of lipid droplets containing 15-d-PGJ2 in macrophages. Sci. Rep. 2017, 7, 1-15. [CrossRef]

55. Iyer, A.; Lim, J.; Poudyal, H.; Reid, R.C.; Suen, J.Y.; Webster, J.; Prins, J.B.; Whitehead, J.P.; Fairlie, D.P.; Brown, L. An inhibitor of phospholipase A 2 group IIA modulates adipocyte signaling and protects against diet-induced metabolic syndrome in rats. Diabetes 2012, 61, 2320-2329. [CrossRef] 
56. Jiménez, N.; Escalante, T.; Gutiérrez, J.M.; Rucavado, A. Skin pathology induced by snake venom metalloproteinase: Acute damage, revascularization, and re-epithelization in a mouse ear model. J. Investig. Dermatol. 2008, 128, 2421-2428. [CrossRef] [PubMed]

57. Bennett, M.; Gilroy, D.W. Lipid Mediators in Inflammation. Microbiol. Spectr. 2016, 4, 1-21. [CrossRef] [PubMed]

58. Honda, T.; Segi-Nishida, E.; Miyachi, Y.; Narumiya, S. Prostacyclin-IP signaling and prostaglandin E2-EP2/EP4 signaling both mediate joint inflammation in mouse collagen-induced arthritis. J. Exp. Med. 2006, 203, 325-335. [CrossRef]

59. Tsuge, K.; Inazumi, T.; Shimamoto, A.; Sugimoto, Y. Molecular mechanisms underlying prostaglandin E2-exacerbated inflammation and immune diseases. Int. Immunol. 2019, 31, 597-606. [CrossRef]

60. Smyth, E.M.; Grosser, T.; Wang, M.; Yu, Y.; FitzGerald, G.A. Prostanoids in health and disease. J. Lipid Res. 2009, 50, 423-428. [CrossRef]

61. Steenport, M.; Khan, K.M.F.; Du, B.; Barnhard, S.E.; Dannenberg, A.J.; Falcone, D.J. Matrix Metalloproteinase (MMP)-1 and MMP-3 Induce Macrophage MMP-9: Evidence for the Role of TNF- $\alpha$ and Cyclooxygenase-2. J. Immunol. 2009, 183, 8119-8127. [CrossRef]

62. Park, J.Y.; Pillinger, M.H.; Abramson, S.B. Prostaglandin E2 synthesis and secretion: The role of PGE2 synthases. Clin. Immunol. 2006, 119, 229-240. [CrossRef] [PubMed]

63. Mitchell, J.A.; Kirkby, N.S. Eicosanoids, prostacyclin and cyclooxygenase in the cardiovascular system. Br. J. Pharmacol. 2019, 176, 1038-1050. [CrossRef]

64. Rucavado, A.; Escalante, T.; Franceschi, A.; Chaves, F.; León, G.; Cury, Y.; Ovadia, M.; Gutiérrez, J.M. Inhibition of local hemorrhage and dermonecrosis induced by Bothrops asper snake venom: Effectiveness of early in situ administration of the peptidomimetic metalloproteinase inhibitor batimastat and the chelating agent CaNa2EDTA. Am. J. Trop. Med. Hyg. 2000, 63, 313-319. [CrossRef] [PubMed]

65. Li, A.; Yu, H.; Li, R.; Liu, S.; Xing, R.; Li, P. Inhibitory effect of metalloproteinase inhibitors on skin cell inflammation induced by jellyfish nemopilema nomurai nematocyst venom. Toxins 2019, 11, 156. [CrossRef] [PubMed]

66. Six, D.A.; Dennis, E.A. The expanding superfamily of phospholipase A2 enzymes: Classification and characterization. Biochim. Biophys. Acta Mol. Cell Biol. Lipids 2000, 1488, 1-19. [CrossRef]

67. Wang, T.; He, C. Pro-inflammatory cytokines: The link between obesity and osteoarthritis. Cytokine Growth Factor Rev. 2018, 44, 38-50. [CrossRef]

68. Fantuzzi, G. Adipose tissue, adipokines, and inflammation. J. Allergy Clin. Immunol. 2005, 115, 911-919. [CrossRef]

69. Tilg, H.; Moschen, A.R. Adipocytokines: Mediators linking adipose tissue, inflammation and immunity. Nat. Rev. Immunol. 2006, 6, 772-783. [CrossRef]

70. Fasshauer, M.; Blüher, M. Adipokines in health and disease. Trends Pharmacol. Sci. 2015, 36, 461-470. [CrossRef] [PubMed]

71. Balistreri, C.R.; Caruso, C.; Candore, G. The role of adipose tissue and adipokines in obesity-related inflammatory diseases. Mediat. Inflamm. 2010, 2010, 1-19. [CrossRef]

72. Viana, M.N.; Leiguez, E.; Gutiérrez, J.M.; Rucavado, A.; Markus, R.P.; Marçola, M.; Teixeira, C.; Fernandes, C.M. A representative metalloprotease induces PGE2 synthesis in fibroblast-like synoviocytes via the NF- $\mathrm{B} / \mathrm{COX}-2$ pathway with amplification by IL-1 $\beta$ and the EP4 receptor. Sci. Rep. 2020, 10, 1-15. [CrossRef]

73. Narumiya, S. Prostanoids and inflammation: A new concept arising from receptor knockout mice. J. Mol. Med. 2009, 87, 1015-1022. [CrossRef]

74. Chowdhury, A.A.; Rahman, M.S.; Nishimura, K.; Jisaka, M.; Nagaya, T.; Ishikawa, T.; Shono, F.; Yokota, K. 15-Deoxy- $\Delta$ 12,14prostaglandin $\mathrm{J} 2$ interferes inducible synthesis of prostaglandins $\mathrm{E} 2$ and $\mathrm{F} 2 \alpha$ that suppress subsequent adipogenesis program in cultured preadipocytes. Prostaglandins Lipid Mediat. 2011, 95, 53-62. [CrossRef]

75. Rahman, M.S. Prostacyclin: A major prostaglandin in the regulation of adipose tissue development. J. Cell. Physiol. 2019, 234, 3254-3262. [CrossRef]

76. Gómez, R.; Conde, J.; Scotece, M.; Gómez-Reino, J.J.; Lago, F.; Gualillo, O. What's new in our understanding of the role of adipokines in rheumatic diseases? Nat. Rev. Rheumatol. 2011, 7, 528-536. [CrossRef]

77. Tanaka, S.; Tatsuguchi, A.; Futagami, S.; Gudis, K.; Wada, K.; Seo, T.; Mitsui, K.; Yonezawa, M.; Nagata, K.; Fujimori, S.; et al. Monocyte chemoattractant protein 1 and macrophage cyclooxygenase 2 expression in colonic adenoma. Gut 2006, 55, 54-61. [CrossRef]

78. Futagami, S.; Hiratsuka, T.; Tatsuguchi, A.; Suzuki, K.; Kusunoki, M.; Shinji, Y.; Shinoki, K.; Iizumi, T.; Akamatsu, T.; Nishigaki, $\mathrm{H}$; ; et al. Monocyte chemoattractant protein 1 (MCP-1) released from Helicobacter pylori stimulated gastric epithelial cells induces cyclooxygenase 2 expression and activation in T cells. Gut 2003, 52, 1257-1264. [CrossRef] [PubMed]

79. Murakami, M.; Kudo, I. Diversity and regulatory functions of mammalian secretory phospholipase A2s. Adv. Immunol. 2001, 77, 163-194. [CrossRef] [PubMed]

80. Dutour, A.; Achard, V.; Sell, H.; Naour, N.; Collart, F.; Gaborit, B.; Silaghi, A.; Eckel, J.; Alessi, M.C.; Henegar, C.; et al. Secretory type II phospholipase A2 is produced and secreted by epicardial adipose tissue and overexpressed in patients with coronary artery disease. J. Clin. Endocrinol. Metab. 2010, 95, 963-967. [CrossRef] [PubMed]

81. Murakami, M.; Taketomi, Y.; Sato, H.; Yamamoto, K. Secreted phospholipase A 2 revisited. J. Biochem. 2011, 150, $233-255$. [CrossRef] [PubMed] 
82. Schaloske, R.H.; Dennis, E.A. The phospholipase A2 superfamily and its group numbering system. Biochim. Biophys. Acta Mol. Cell Biol. Lipids 2006, 1761, 1246-1259. [CrossRef]

83. Garces, F.; López, F.; Nĩo, C.; Fernandez, A.; Chacin, L.; Hurt-Camejo, E.; Camejo, G.; Apitz-Castro, R. High plasma phospholipase A 2 activity, inflammation markers, and LDL alterations in obesity with or without type 2 diabetes. Obesity 2010, 18, 2023-2029. [CrossRef]

84. Hernandez-Anzaldo, S.; Berry, E.; Brglez, V.; Leung, D. Yun, T.; Lee, J.S.; Filep, J.G.; Kassiri, Z.; Cheong, C.; Lambeau, G.; et al. Identification of a Novel Heart-Liver Axis: Matrix Metalloproteinase-2 Negatively Regulates Cardiac Secreted Phospholipase A2 to Modulate Lipid Metabolism and Inflammation in the Liver. J. Am. Heart Assoc. 2015, 4, e002553. [CrossRef] [PubMed]

85. Berry, E.; Hernandez-Anzaldo, S.; Ghomashchi, F.; Lehner, R.; Murakami, M.; Gelb, M.H.; Kassiri, Z.; Wang, X.; Fernandez-Patron, C. Matrix metalloproteinase-2 negatively regulates cardiac secreted phospholipase A2 to modulate inflammation and fever. J. Am. Heart Assoc. 2015, 4, e001868. [CrossRef]

86. Lambert, C.; Zappia, J.; Sanchez, C.; Florin, A.; Dubuc, J.E.; Henrotin, Y. The Damage-Associated Molecular Patterns (DAMPs) as Potential Targets to Treat Osteoarthritis: Perspectives From a Review of the Literature. Front. Med. 2021, 7, 607186. [CrossRef]

87. Qi, H.Y.; Shelhamer, J.H. Toll-like receptor 4 signaling regulates cytosolic phospholipase A2 activation and lipid generation in lipopolysaccharide-stimulated macrophages. J. Biol. Chem. 2005, 280, 38969-38975. [CrossRef] [PubMed]

88. Gutiérrez, J.M.; Escalante, T.; Rucavado, A.; Herrera, C.; Fox, J.W. A Comprehensive View of the Structural and Functional Alterations of Extracellular Matrix by Snake Venom Metalloproteinases (SVMPs): Novel Perspectives on the Pathophysiology of Envenoming. Toxins 2016, 8, 304. [CrossRef]

89. Holinstat, M.; Boutaud, O.; Apopa, P.L.; Vesci, J.; Bala, M.; Oates, J.A.; Hamm, H.E. Protease-activated receptor signaling in platelets activates cytosolic phospholipase A2 $\alpha$ differently for cyclooxygenase- 1 and 12-lipoxygenase catalysis. Arter. Thromb. Vasc. Biol. 2011, 31, 435-442. [CrossRef] [PubMed]

90. Burhans, M.S.; Hagman, D.K.; Kuzma, J.N.; Schmidt, K.A.; Kratz, M.; Program, P.; Cancer, F.H. Contribution of adipose tissue inflammation to the development of type 2 diabetes HHS Public Access. Physiol. Behav. 2019, 9, 1-58. [CrossRef]

91. Plebańczyk, M.; Radzikowska, A.; Burakowski, T.; Janicka, I.; Musiałowicz, U.; Kornatka, A.; Maśliński, W.; Kontny, E. Different Secretory Activity of Articular and Subcutaneous Adipose Tissues from Rheumatoid Arthritis and Osteoarthritis Patients. Inflammation 2019, 42, 375-386. [CrossRef] [PubMed]

92. Locati, M.; Lamorte, G.; Luini, W.; Introna, M.; Bernasconi, S.; Mantovani, A.; Sozzani, S. Inhibition of monocyte chemotaxis to C-C chemokines by antisense oligonucleotide for cytosolic phospholipase A2. J. Biol. Chem. 1996, 271, 6010-6016. [CrossRef] [PubMed]

93. Amiable, N.; Tat, S.K.; Lajeunesse, D.; Duval, N.; Pelletier, J.P.; Martel-Pelletier, J.; Boileau, C. Proteinase-activated receptor (PAR)-2 activation impacts bone resorptive properties of human osteoarthritic subchondral bone osteoblasts. Bone 2009, 44, 1143-1150. [CrossRef] [PubMed] 